TOM D.

DILLEHAY:

Departamento de

Antropologia da

Universidade

de Kentucky, EUA.
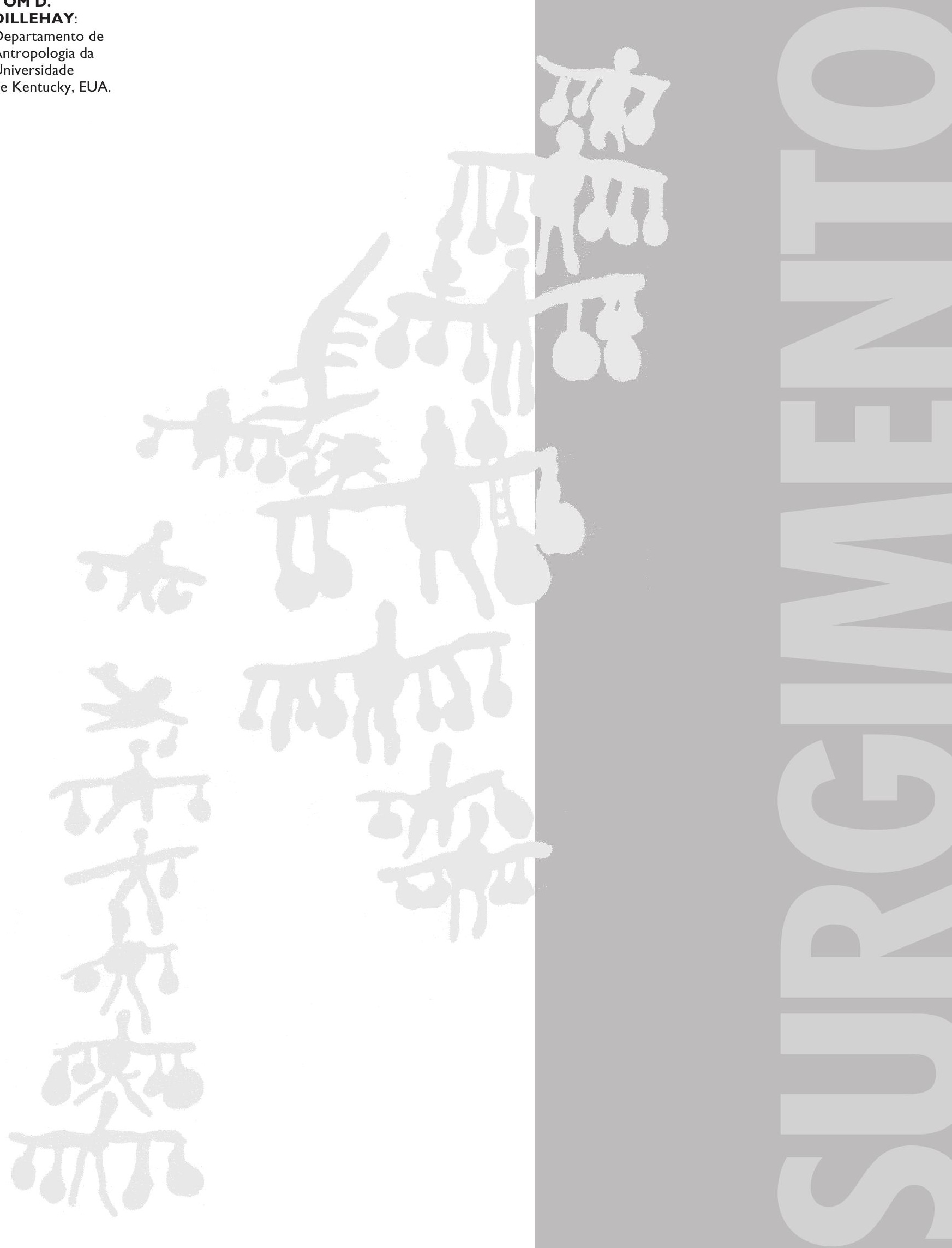


\section{Onde estão os}

\section{remanescentes}

\section{ósseos humanos do}

\section{final do Pleistoceno?}

\section{Problemas}

\section{e perspectivas \\ na procura dos \\ primeirros americanos}

T O D D. DILLEHAY 
INTRODUÇÃO

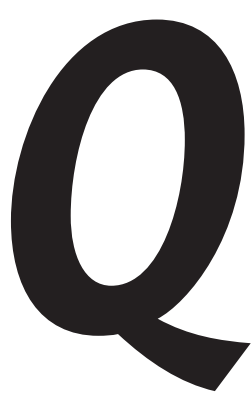

uando foi que o homem entrou pela primeira vez no Novo Mundo?Como chegou até aqui? Que tipos de tecnologia, economia e organização social possuía? Como era sua constituição biológica? Quais eram suas crenças religiosas? Onde e como enterrou seus mortos? Como se ajustou e qual foi seu impacto na vida animal e vegetal da idade glacial nas Américas? Não há respostas claras para essas e outras perguntas. Durante o último meio século, a opinião geral era que os famosos caçadores Clóvis, armados com seus projéteis de pontas acanaladas, foram os primeiros humanos a atravessar da Sibéria ou do nordeste da Ásia para o Alasca, entre 11.000 e 11.500 anos atrás, colonizando o Novo Mundo (Meltzer, 1989; Lynch, 1990; Bryan, 1991; Stanford, 1991). Caso aceitemos essa visão, isso não explica como a técnica das pontas acanaladas chegou até a Terra do Fogo (como se deduz das conhecidas pontas de projétil "rabo-de-peixe"), na extremidade final da América do Sul, aproximadamente ao mesmo tempo que apareceu na América do Norte. Nem explica como até agora não se encontraram evidências no Alasca da existência de sítios do tipo Clóvis. Uma alternativa é que os humanos atravessaram antes de 12.000 anos, trazendo uma cultura pré-Clóvis diferente e menos especializada, e que a técnica da acanaladura se espalhou mais tarde. Essa hipótese foi comprovada no ano passado pela aceitação do sítio de Monte Verde na região centro-sul do Chile, commais de 12.500 anos (ver Meltzer, 1997).

Entretanto, ainda resta um problema. São escassas ou faltam inteiramente evidências diretas da estrutura física e genética dos primeiros americanos no período

Tradução de Ramon Arthur Clark

Ver a contribuição de Neves et alii neste dossiê para uma opinião distinta sobre o problema (nota dos organizadores).
Norte, constituindo assim a América oúnico continente do planeta onde sabemos da existência humana pré-histórica quase que exclusivamente através dos artefatos e não pelos restos de esqueletos humanos. Por que, para esse período, os registros de esqueletos humanos são tão escassos nas Américas, especialmente quando os registros do começo do período Arcaico, que o sucede (ca. 7.000 - 9.800 antes do presente), são relativamente abundantes? Quem sabe, uma vez que se encontre uma resposta para essa pergunta, seja possível compreender melhor outros aspectos sutis e controversos quanto ao tópico "povoamento" do Novo Mundo.

O que mais complica a questão é a presença de dois tipos de esqueletos humanos antigos na América do Sul (Chauchat, 1987), datados do final do Pleistoceno ao início do Holoceno: uma forma robusta e uma grácil. Essa diversidade precoce de tipos de população humana levanta questões importantes a respeito da data de entrada, da direção dessa entrada e dos tipos humanos que entraram no Novo Mundo. O que fornece uma nova luz sobre esse assunto em particular são os resultados de recentes estudos craniomorfológicos de restos humanos pré-históricos de várias localidades do hemisfério ocidental. Esses estudos sugerem que os sul-americanos antigos mais conhecidos não apresentavam a esperada afinidade morfológica com os norteasiáticos ou com os siberianos, mas sim com as populações do Pacífico Sul e sulasiáticos (cf. Lahr, 1996; Steele e Powell, 1992; Neves e Pucciarelli, 1990; Neves et alii, 1993). Esses dados são complementados pelos dos geneticistas, os quais também indicam afinidades fortes das populações sulamericanas com as sul-asiáticas (Zago, 1995), bem como com as populações asiáticas em geral (Torronie Wallace, 1995). Esses estudos, junto com novas descobertas arqueológicas pleistocênicas, estão nos forçando a reconsiderar seriamente a origem e a natureza dos primeiros povos que habitaram as Américas.

Neste ensaio explorarei brevemente dois pontos: 1) a natureza e o significado da falta 
de registros de esqueletos humanos do final do Pleistoceno na América do Sul, em relação às práticas e crenças mortuárias pré-históricas; e 2) as implicações de uma maior diversidade de tipos de esqueletos nas Américas.

\section{- PRIMEIRO PONTO: ONDE ESTÃO OS OSSOS?}

Dos vários possíveis indicadores arqueológicos dos povos existentes nas Américas no final do Pleistoceno, as práticas de sepultamento constituem o de documentação mais escassa. Até agora, ainda não se atribuiu aos primeiros americanos o ato de sepultamento deliberado, isso até o começo do período Arcaico (ca. 9.500 a.p.). Muitos arqueólogos e antropólogos físicos (Lahr, 1996; Neves e Pucciarelli, 1990; Neves et alii, 1993) se referem a restos de esqueletos humanos que datam do final da época glacial, mas nenhum deles foi encontrado por arqueólogos. Algumas poucas ossadas humanas foram encontradas em sítios da época glacial, mas esses restos são fragmentados, derivados de contextos questionáveis e/ou não foram datados por radiocarbono com segurança. Taylor et alii (1985), por exemplo, demonstraram que a análise de radiocarbono de ossos humanos de vários supostos sítios pré-históricos norte-americanos, aos quais atribuíam-se anteriormente idades que variavam de aproximadamente 15.000 a 70.000 anos atrás, sugere que nenhum desses esqueletos é mais antigo que 10.600 anos, e que os mais antigos encontram-se na América do Norte. Dois sítios são datados do meio do décimo milênio: o sítio Wilsall, em Montana, e o sítio Mostin, na Califórnia. As evidências de esqueletos humanos mais antigos conhecidos, na América do Sul, vêm dos sítios de Las Vegas, no Equador, de Lauricocha e Paijan, no Peru, da Lapa Vermelha, no Brasil, e de La Moduna, na Argentina, todos datados entre $7.000 \mathrm{e}$ 9.500 anos antes do presente (2).

A diversidade do ato de sepultar nesses sítios, do começo do período Arcaico (e em outros sítios posteriores também), sugere que o sepultamento era um costume relativamente formal e que ainda não tinha sido culturalmente restrito a uma única forma na maioria das regiões. Há sepultamentos primários e secundários, com pequena variação na orientação e tratamento dos esqueletos, inclusive com a presença de ocre vermelho espargido sobre os ossos, os quais foram descobertos em uns poucos sítios no noroeste da Argentina (Gonzalez, 1985), no Peru Central (Quilter, 1989) e no norte do Chile (Allisson, 1985). A presença de ambas as práticas funerárias, primária e secundária, pode estar relacionada à natureza nômade e seminômade dos padrões de assentamento do período Arcaico. Muitos dos sepultamentos eram individuais, mas alguns eram múltiplos (Stothert, 1985; Quilter, 1989; Schiappacasse e Niemeyer, 1984). Alguns dos esqueletos estavam estendidos, outros muito flexionados e o restante dos corpos estava frouxamente contraído. Em outras instâncias, prescreveuse aparentemente o enterro em covas rasas, a poucos metros das habitações, o que sugere provavelmente serem os indivíduos enterrados habitantes daquela estrutura. E alguns corpos frequientemente eram colocados em covas feitas nos aterros de lixo de sítios anteriormente ocupados como locais de moradia. Geralmente, os povos do início do período Arcaico preocupavam-se tanto com a morte quanto com a vida. O tratamento dispensado aos mortos era usualmente cuidadoso e detalhado, o que sugere que talvez práticas semelhantes, embora menos sofisticadas, existiram no final do Pleistoceno, mas ainda não foram detectadas.

A evidência esqueletal faltante ou mesmo escassa nas Américas no final do Pleistoceno torna-se especialmente intrigante se considerarmos que os registros arqueológicos pré-históricos do Velho Mundo caracterizam-se pela presença de restos pré-humanos e humanos que se estendem a 2.000.000 anos em algumas áreas, e que a partir de 50.000 a.p. passam a se caracterizar por padrões e rituais de sepul-
2 Para uma opinião diferente ver Neves et alii neste dossiê (nota dos organizadores) 
tamento muito bem definidos. De fato, pela primeira vez na história humana, os povos neandertais da Europa e da Ásia (ca. 60.000 a.p.) praticam os rituais de sepultamentouma atividade unicamente humana (Trinkhaus e Shipman, 1992). Por exemplo, no sítio de Le Moustier, na região do Perigord, França, o corpo de um adolescente neandertal foi depositado numa cova,

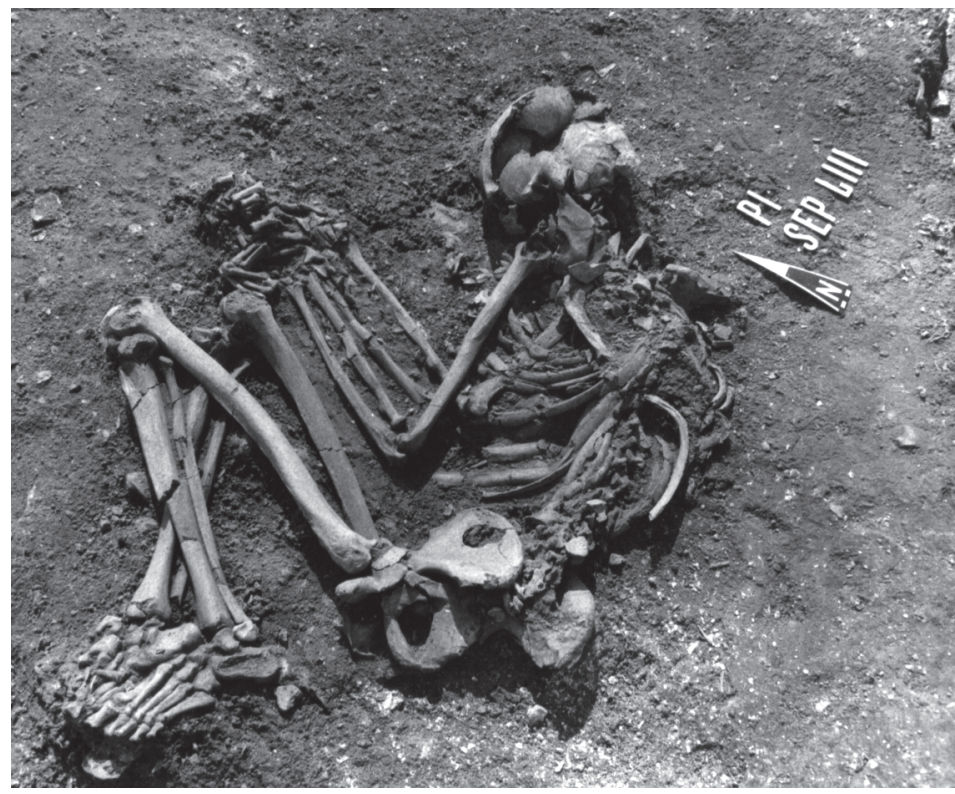

Esta foto e as seguintes são enterramentos do Sambaqui

Piaçaguera, município de Cubatão (SP), em terrenos da Cosipa ça apoiada no antebraço como se estivesse jazendo sobre seu lado direito, com a cabedormindo. Uma pilha de blocos de sílex serviu de travesseiro um machado de pedra bem lascada foi depositado perto de sua mão. Ao redor do corpo foram espalhados ossos de uma vaca selvagem. Alguns préhistoriadores especulam que esses ossos estavam cobertos de carne à época da partida do adolescente para o outro mundo, como sustento para sua viagem ao além.

Num outro sítio no Perigord, La Ferrassie, descobriram-se os restos de seis indivíduos, um homem, uma mulher, duas crianças jovens e dois bebês. A mulher foi enterrada numa posição fetal exagerada, com os joelhos colocados apertadamente contra o peito. Quanto ao homem, aparentemente uma placa de pedra foi deliberadamente colocada por cima de sua cabeça e ombros, e este foi enterrado com lascas de pedra e ossos. Uma outra placa, aparentemente associada ao enterro de uma das crianças, parece ter sido marcada com buraquinhos num dos lados e com ocre vermelho no outro.

Distante dali, em Telshik Tash, no Uzbequistão, Ásia Central, uma criança jovem foi sepultada com um anel de seis pares de ossos de ibex ao redor de sua cabeça. E numa caverna de 60.000 anos de idade, em Shanidar, nas montanhas Zagros, no Iraque, foram encontrados os restos de pelo menos nove indivíduos. Um deles, um homem provavelmente morto por uma queda de rochas aos 40 anos de idade, foi enterrado com diversas flores, indicadas pela presença de pólen de plantas exóticas na sepultura.

Comparados aos sítios-cemitérios muito elaborados dos primeiros humanos modernos verdadeiros (Homo sapiens), aqueles dos neandertais eram muito simples e rústicos. Entretanto, o fato de ter ocorrido algum tipo de ritual na época dos neandertais é um testemunho eloqüente da compreensão elevada da vida e da mortee de alguma coisa transcendental na própria vida. Isso, seguramente, é um bom critério pelo qual podemos identificar uma atividade humana - mais ainda do que através da presença de líticos, estrutura e outros artefatos. Até agora, nada parecido foi descoberto antes dessa época nos registros pré-históricos do Velho Mundo, ainda que se encontrem restos esqueletais ou préhumanos. Parece que um limiar importante na evolução foi cruzado pelos neandertais.

Padrões de sepultamento semelhantes aparecem na Austrália, um continente, assim como as Américas, habitado mais tardiamente no Pleistoceno. As evidências arqueológicas provenientes da Austrália sugerem que a chegada de seres humanos ali ocorreu por volta de 40.000 ou possivelmente 50.000 a 60.000 anos atrás (Allen e O'Connell, 1995). Restos esqueletais apareceram em diversos sítios datados entre 10.000 e 30.000 anos atrás. Os restos consistem em sepultamentos individuais e grupais, encontrados em sítios enterrados em terraços aluviais, cavernas, abrigos sob-rocha e pântanos. Muitas vezes esses sepultamentos estavam associados a rituais e oferendas. 
Visto que sítios de sepultamento de seres humanos foram encontrados por toda a Europa, Ásia e Austrália, desde aproximadamente 50.000 anos, e que dali sairiam os ancestrais dos primeiros americanos, então por que não encontramos mais restos esqueletais humanos da era glacial no Novo Mundo? Essa falta ou pobreza sugere diversas possibilidades: 1) viés metodológico que nos desvia dos locais de sepultamento, o que significa que simplesmente não estamos procurando os restos humanos nos lugares certos porque pensamos saber onde os povos pré-históricos moravam e enterravam seus mortos; 2) invisibilidade arqueológica, o que significa que muitos sítios de sepultamentos pré-históricos foram cobertos pela atividade geológica; 3 ) práticas de sepultamento destrutivas ou inconspícuas, o que significa que os primeiros americanos destruíam os restos de seus mortos, não praticavam o sepultamento em grupo, ou possuíam ideologia e prática mortuária diferentes; 4) os ossos humanos foram datados com radiocarbono contaminado, o que significa possivelmente termos descoberto alguns dos primeiros americanos, mas as leituras de radiocarbono deles derivadas, estando contaminadas, geraram datas mais recentes (mas isso é pouco provável tendo em vista os meios sofisticados disponíveis aos cientistas para detectar contaminadores); 5) qualquer combinação dos fatores acima ou de outros.

Nós arqueólogos assumimos que os primeiros americanos sepultaram seus mortos e praticaram rituais funerários padronizados muito parecidos com aqueles dos seus predecessores do Velho Mundo e os de seus sucessores do início do período Arcaico. Mas este pode não necessariamente ser o caso. Alguns dos primeiros americanos podem ter matado uns aos outros, e até mesmo ter comido uns aos outros. Isso não necessariamente significa que estivessem com fome, mas podem ter sido canibalizados como parte de um ritual. Eles também podem ter cremado os corpos e espalhado os restos em locais especiais, tais como brejos, pântanos, ou fendas rochosas, distantes dos sítios de moradia. Sendo assim, os arqueólogos (que geralmente são mais suscetíveis de encontrar sítios habitacionais, sítios de extração de matéria-primas e outros locais conspícuos de atividades humanas) teriam pouca possibilidade de encontrar restos de esqueletos intactos.

Pode ser também que os primeiros americanos tenham tido um sistema de crença e padrão de uso da terra diferentes - as populações Clóvis não ocuparam cavernas (Kelley e Todd, 1988), um local de ocupação humana muito popular no resto do mundo em todas as épocas. Os arqueólogos da América do Norte verificaram que as cavernas e abrigos sob-rocha foram pouco ocupados pelos paleoíndios, tanto os do início do período como os do final (pósClóvis) (Collins, 1991; Tankersley, 1990). Kelley e Todd (1988, p. 235) propuseram mesmo que as cavernas não eram utilizadas pelos primeiros imigrantes (que, para estes autores, são os povos Clóvis), principalmente porque a rápida mobilidade excluía o conhecimento de sua localização e o uso prolongado das mesmas. De acordo

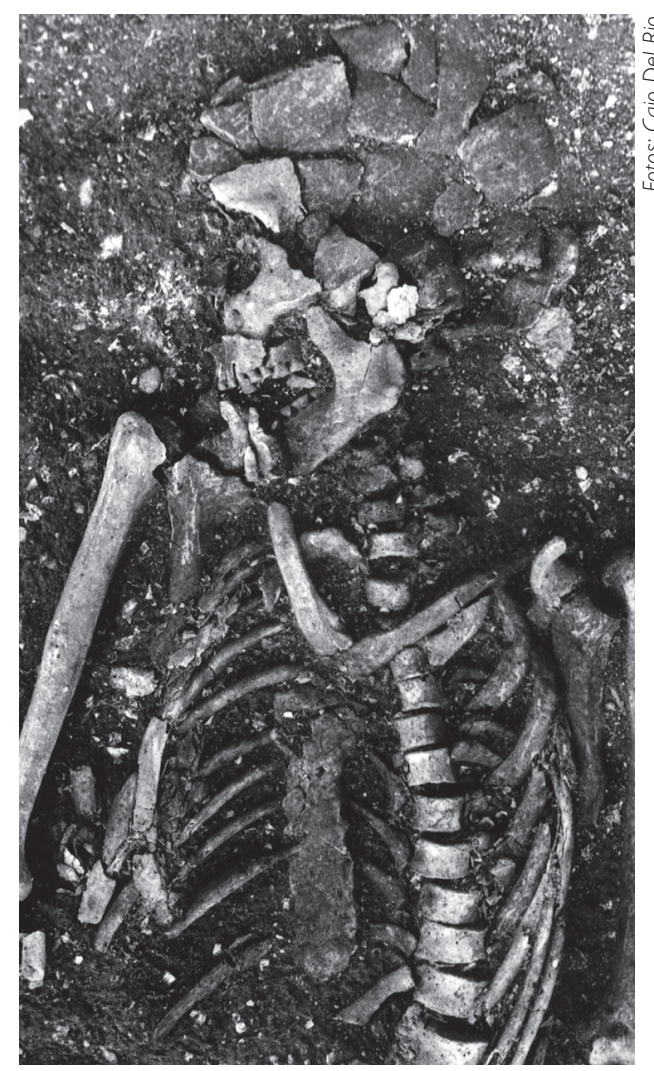


com Kelley e Todd, esses povos simplesmente não teriam o tempo necessário para se familiarizar com os recursos locais e, portanto, não habitaram nem mesmo cavernas bastante hospitaleiras. Seguindo o pensamento de Kelley e Todd, poderíamos argumentar que foi a alta mobilidade que tornou a falta de padrões e rituais funerários traços adaptativos. Se estivermos corretos, não encontraremos sepultamentos humanos em cavernas e abrigos. Se os restos humanos não foram enterrados nas cavernas, então devem ser localizados em outros lugares, talvez em qualquer ponto ao longo dos caminhos de deslocamento ou em locais onde a abertura de uma cova fosse mais fácil e onde o defunto pudesse ser disposto prontamente - padrões de sepultamentos que não exigiriam uma ideologia e um comprometimento funerário sofisticados. Para mim esse argumento faz pouco sentido. Os neandertais, seus predecessores, assim como os ancestrais dos primeiros americanos, eram seguramente tão altamente móveis, se não mais, que os povos Clóvis e pré-Clóvis, e encontramos seus restos esqueletais não apenas em cavernas, mas também em sítios ao ar livre. De fato, a população humana que saiu da Ásia e povoou o Novo Mundo em primeiro lugar era altamente móvel. A evitação subseqüente das cavernas pelas populações Clóvis contrasta frontalmente com os padrões de ocu- pação da paisagem praticados pelas populações ancestrais européias e asiáticas.

Ademais, como é que a falta de familiarização com a paisagem local poderia excluir o uso de cavernas pelos imigrantes iniciais quando estes mesmos povos possuíam conhecimento íntimo suficiente da matéria-prima lítica local para fabricar ferramentas de pedra, bem como dos recursos alimentares locais para sustentá-los biologicamente? Visto que eram bastante familiarizados com o terreno local para encontrar estes recursos cruciais, seguramente teriam achado as cavernas para se abrigarem, as quais provavelmente se encontravam dentro ou perto das mesmas formações rochosas de onde extraíam matéria-prima lítica. Para concluir este ponto, a alta mobilidade seguramente desempenhou um papel na seletividade e longevidade de alguns padrões de uso da terra. Mas certamente desempenhou um papel muito menor na formação do registro inconspícuo dos remanescentes esqueletais antigos das Américas. É mais provável que as razões da ausência desses restos sejam as seguintes: 1) identificação e amostragem arqueológica insuficientes de toda a gama de tipos de sítios usados pelos primeiros imigrantes; e 2) a prática de sistemas de crenças e funerários diferentes.

Levando-se em conta a tecnologia relativamente simples dos primeiros america-

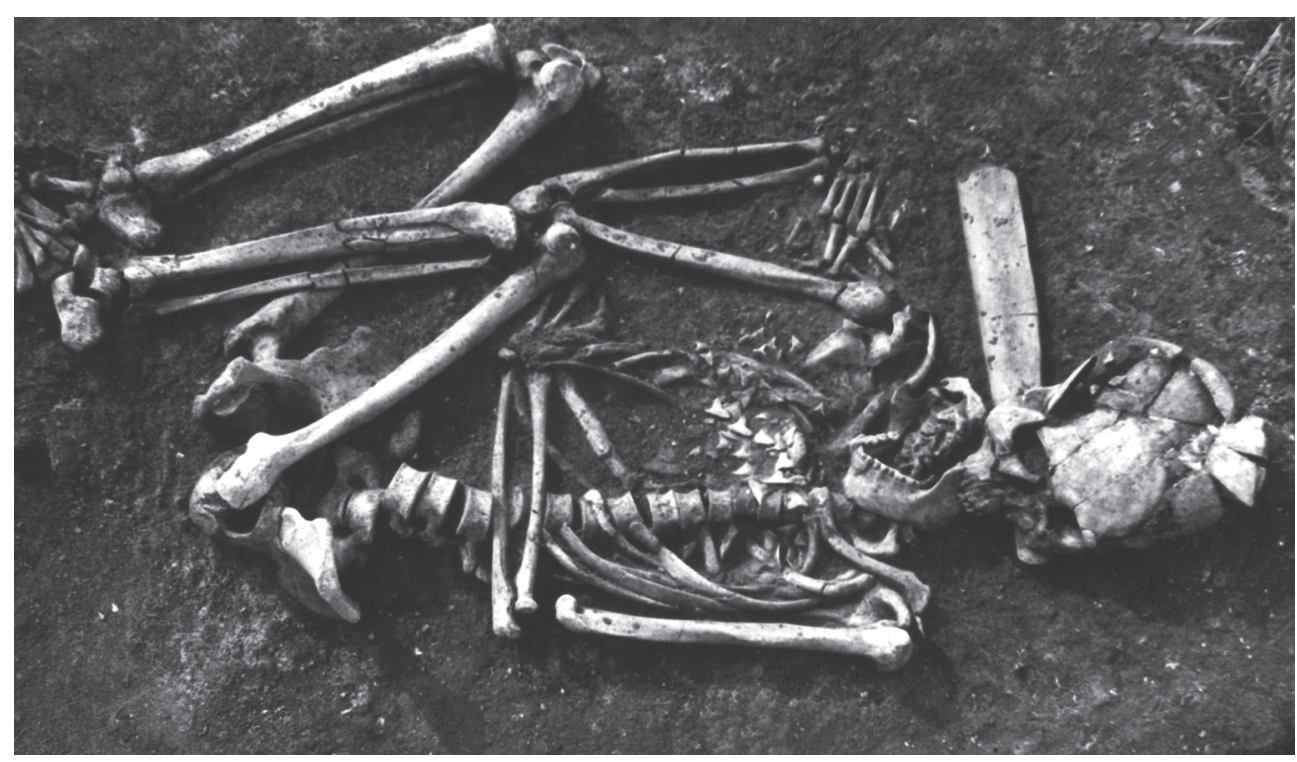


nos, podemos esperar encontrar corpos dispostos em locais onde fosse fácil abrir uma cova ou onde se pudesse colocar convenientemente um corpo dentro de uma fenda natural, uma caverna ou um sumidouro (3). A intenção pode ter sido simplesmente enterrar o corpo num local conveniente onde estaria protegido das intempéries climáticas, bem como de predadores. Tais locais poderiam ser dunas de areia ou outros depósitos sedimentares arenosos ou mesmo macios, embaixo de arestas rochosas ou dentro de fendas rochosas, em pântanos e brejos, ou talvez em sumidouros, arroios ou cânions. Seja qual for o caso, parece ter existido um padrão: os lugares mais conspícuos - os sítios habitacionais, especialmente cavernas e abrigos rochosos, pedreiras e sítios de caça - não foram usados para enterrar os mortos. Isso significa que a pobreza de evidências dos primeiros esqueletos humanos é simplesmente conseqüência da amostragem arqueológica: não conseguimos localizar ainda os sítios dos primeiros americanos.

A pobreza de evidências pode também ser explicada pela experiência um tanto única dos primeiros americanos enquanto Homo sapiens sapiens modernos. Eles conseguiram algo nunca antes conseguido pelos homens modernos (com a possível exceção dos primeiros australianos): conquistaram biológica e culturalmente uma paisagem anteriormente desabitada. Certamente essa experiência adaptativa única acelerou a invenção e a aculturação, bem como o abandono de traços mal-adaptados, tais como o enterramento deliberado dos mortos em sítios habitacionais (inclusive cavernas e abrigos sob-rocha), um traço trazido do Velho Mundo. Já sabemos que alguns dos primeiros americanos, ou seja, os povos Clóvis, possuíam uma tecnologia lítica distinta, a indústria das pontas acanaladas. Portanto, por que não poderiam possuir, também, um padrão de enterramento distinto? É também possível que nem todos os primeiros americanos enterrassem seus mortos, ou que alguns apenas os enterrassem de tempos em tempos, aqui e ali, dependendo das circunstân- cias locais. O ponto é que não foram efetuados rituais funerários padronizados e arqueologicamente conspícuos. Isso implica que os primeiros americanos constituíram uma sociedade que não enterrava seus mortos?

A idéia de uma sociedade que não enterrava seus mortos, no final da idade glacial, parece ser especialmente difícil de aceitar, possivelmente porque desafia algumas das definições ocidentais do que nos torna humanos. Parece também um argumento no sentido de alguma forma de "involução" cultural na América antiga (embora o ato de enterrar tenha existido no período Arcaico), visto que os primeiros europeus e asiáticos sepultaram os mortos em covas e, muitas vezes, efetuaram rituais de enterramento. Parece-me que, de acordo com nosso conhecimento atual, a explicação mais parcimoniosa das evidências é aquela que explica ambos, os registros biológicos e arqueológicos existentes. Isso parece sugerir um conjunto diferente de traços que atuaram no povoamento das Américas - traços esses relacionados a diferentes formas de organização social, tecnologia e padrão de uso da paisagem, atualmente pouco compreendidos. Quando começarmos a entender esses aspectos dos registros do povoamento e de como estão relacionados a mudanças nas adaptações biológicas é que começaremos, então, a entender os padrões de sepultamento. O ponto de partida, entretanto, é encontrar evidência esqueletal. Isso significa que devemos começar a procurar numa maior variedade de lugares (Dillehay e Meltzer, 1991), e ficar de mentes abertas e com as nossas estratégias de pesquisa flexíveis e interdisciplinares.

\section{- SEGUNDO PONTO: AS FORMAS ESQUELETAIS ROBUSTAS E GRÁCEIS}

Até agora o cenário mais aceito quanto ao povoamento das Américas está sintetizado no Modelo das Três Migrações, de
3 Este quadro refere-se exclusivamente à América do Norte, não se aplicando à América do Sul (nota dos organizadores) 
Christy Turner II (1983), que se baseia nas suposições de que o hemisfério foi ocupado em épocas recentes (pós 12.000 a.p.), que apenas três migrações deram origem à elevada diversidade biológica e cultural das populações nativas americanas, e que todas as populações fundadoras são de descendência mongolóide (nordeste-asiática e siberiana). De acordo com esse modelo, alcançaram a América do Sul em primeiro lugar grupos humanos chamados de paleoíndios, pertencentes à primeira migração, o que ocorreu ao redor de 10.000 a.p.

Recentemente, tanto os antropólogos físicos quanto os arqueólogos vêm questionando seriamente o modelo de migração tripla. Alguns arqueólogos acreditam que o lapso de tempo de permanência dos seres humanos no Novo Mundo é maior, e consideram o modelo de Turner muito simplista empiricamente e restritivo temporalmente. Antropólogos físicos, por seu lado, ao estudar a morfologia craniana de restos humanos dos primeiros sítios arcaicos, tanto na América do Sul como do Norte, sugeriram recentemente que populações nãomongolóides também entraram no Novo Mundo(4) (Nahr, 1995; Neves e Pucciarelli, 1990; Neves et alii, 1993; Steele e Powell, 1992). Esses achados levantaram a possibilidade de uma quarta migração, mais antiga. Frisa-se nesses estudos que, para se aceitar o Modelo das Três Migrações para a América do Sul, a diversidade craniana observada teria que se enquadrar num mesmo padrão geral, o que parece não ser o caso. Ao testar essa proposta, os sul-americanos Walter Neves, Hector Pucciarelli e outros realizaram análises uni-, bi- e multivariadas extensivas sobre as medidas cranianas tomadas de esqueletos humanos antigos bem como de nativos sul-americanos modernos. Os resultados de seus estudos mostraram que durante o início do período Arcaico, a morfologia do crânio humano na América do Sul experimentou uma mudança dramática, que melhor se explica através de uma substituição genética, e não pela continuidade morfológica resultante de migrações seqüenciais da mesma população mongolóide fundadora. Neves e seus colegas, especialmente, acreditam que a primeira migração entrante dos nãomongolóides ocorreu ao redor de 12.000 a.p., se não mais cedo, enquanto que uma segunda, desta vez de mongolóides típicos, entrou ao redor de 9.000 ou 8.000 a.p. Caso Neves e seus colegas estejam certos, seria possível aos arqueólogos demonstrar terem ocorrido mudanças culturais significativas no início do período Arcaico, bem como documentar uma maior antigüidade nos registros arqueológicos da América do Sul, o que tem sido o caso (cf. Ardila e Politis, 1989; Dillehay et alii, 1992).

De uma perspectiva arqueológica, Chauchat (1988) observou uma diferença morfológica entre esqueletos arcaicos dos lados Pacífico e Atlântico da América do Sul. Ele atribui essas diferenças a padrões de subsistência e adaptação regional, mais que a genéticos e de continuidade migracional.

"No começo [mais apropriadamente no fim] do Pleistoceno, quase todos os esqueletos são dolicocefálicos [robustos], enquanto no período posterior [início do Holoceno] os esqueletos são do tipo curto braquicefálico por causa da contribuição maciça de crânios do tipo mongolóide [grácil]. Apesar desta diferença pronunciada, sem qualquer indicação de evolução, uma divergência racial já existe no começo do povoamento do continente, sendo o tipo Paijan diverso dos outros esqueletos conhecidos (Lauricocha, Lagoa Santa, La Moduna). Mas a distribuição e o hábitat bem como os hábitos alimentares são os fatores específicos responsáveis por essa diversidade" (Chauchat, 1988, p. 88).

Obviamente são necessárias muito mais evidências esqueletais de sítios sistematicamente estudados antes que possamos confirmar o papel da genética, da migração e/ou das adaptações locais na produção das diferenças nos esqueletos observados pelos antropólogos físicos e pelos arqueólogos. O importante a reconhecer é que as diferenças biológicas geralmente correspondem a distinções culturais significati- 
vas observadas ao longo do continente nos registros arqueológicos do mesmo período. Grande parte da variação cultural provavelmente se relaciona a adaptações locais e a combinações de traços "herdados" trazidos do Velho Mundo, além de traços novos (por exemplo: a técnica da ponta acanalada) desenvolvidos no Novo Mundo. Não compreendida é a diversidade biológica.

Ao tentar explicar uma divergência biológica inicial semelhante, que ocorreu no Velho Mundo, os especialistas têm empregado dois modelos. Um é conhecido como o modelo de "continuidade regional" (Wolpoff, 1989). O outro é o modelo da “substituição" (Cann et alii, 1987). Se considerarmos a aplicabilidade desses modelos ao Novo Mundo, pelo modelo da continuidade regional haverá uma linha evolutiva levando a forma robusta à grácil. Pensa-se que a forma grácil representaria a incursão de mongolóides que se cruzaram com a população robusta e não-mongolóide previamente existente, o que deu origem ao ameríndio moderno. Enquanto os biólogos aparentemente acham esse modelo atraente, pois consideram em primeiro lugar as características morfológicas, é difícil conciliá-lo com a evidência arqueológica, pois as datas para as formas robustas e gráceis são as mesmas tanto na América do Norte como na do Sul. É necessária uma data mais antiga para a forma robusta para tornar o modelo de continuidade regional válido. Também surge a questão do porquê da forma robusta, que se presume ser a mais antiga das duas, existir até o período Arcaico, que vem a ser o caso em partes da América do Sul. O modelo de continuidade regional está também em conflito com o modelo de substituição, o qual se baseia em estudos do DNA. De acordo com esse último modelo, a população grácil ou ameríndia substituiu a população nãomongolóide, o que explicaria parte da diversidade genética e morfológica observada nos primeiros esqueletos arcaicos da América.

O uso das evidências arqueológicas que se concentram mais nos aspectos culturais do que nos biológicos não apóia fortemente nenhum dos dois modelos. A alta diversidade de material arqueológico sugere populações humanas diversas e migrações diferentes. Sugere, entretanto, a substituição de uma população pela outra, quando consideramos a presença de populações préClóvis. Isto é, uma forma robusta pré-Clóvis pode ter sido assimilada ou substituída em algumas áreas pelos povos Clóvis posteriores. Entretanto, no momento não há nenhuma evidência esqueletal apoiando essa possibilidade.

Embora sejam necessários mais dados arqueológicos e biológicos para resolver esses problemas, pode-se dizer que o melhor modelo apoiado nas evidências exis-

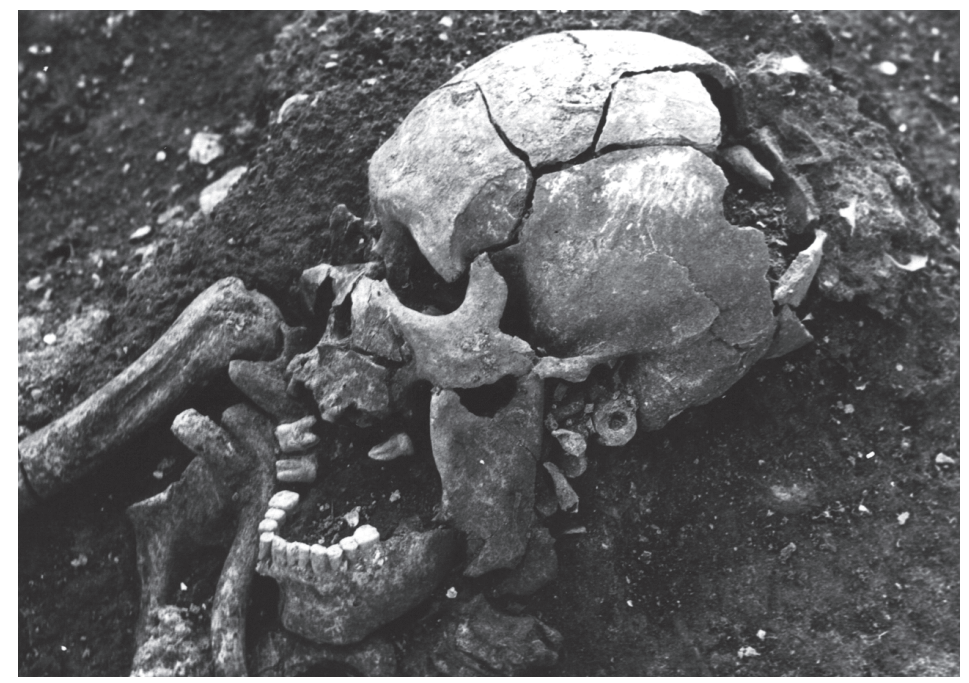

tentes é o seguinte: nas Américas, os primeiros Homo sapiens sapiens robustos provavelmente representavam uma população com um mínimo de cultura material contemporânea de (mas só mais tarde assimilada por) grupos gráceis posteriores, num tempo ainda indefinido no final do Pleistoceno. Os registros esqueletais existentes de populações gráceis do período Arcaico representam principalmente mongolóides com uma origem asiática, possivelmente com uma herança cultural que se estende no passado até o $11^{\circ}$ ou $12^{\circ}$ milênio. O "elo perdido" ou ancestral pode ter sido o tipo robusto, que pode ter entrado no Novo Mundo antes de 12.000 anos atrás, como desejam Neves e colegas. Esse elo 
pode ser do tipo pré-Clóvis, possuindo afinidades genéticas e morfológicas principalmente com o sul da Ásia e o sul do Pacífico.

Em suma, sejam quais forem a data de entrada e o(s) vetor(es) geográfico(s) implicados nos movimentos para as Américas, as diferenças morfológicas observadas nos registros esqueletais existentes (e escassos) do começo do período Arcaico da América do Sul apresentam implicações óbvias quanto a padrões de fluxo genético e transmissão de informações culturais, bem como ao tipo de Homo sapiens sapiens social e biológico que colonizou a América do Sul. Para se ter uma melhor compreensão dessas suposições, deve-se aguardar a recuperação de maiores dados arqueológicos, genéticos (Salzano, 1995; Bianchi et alii, 1995), e de esqueletos humanos de sítios bem escavados e sistematicamente estudados.

\section{CONCLUSÃO}

No momento existem evidências sólidas que indicam a chegada de seres humanos ao Novo Mundo antes de 12.000 anos atrás, e que as populações Clóvis não foram as primeiras a imigrar do Alasca até a Terra do Fogo. O fato de não termos conseguido até agora localizar os restos mortais desses primeiros povos, inclusive os dos povos Clóvis, sugere uma singularidade inerente aos primeiros americanos ou ao tipo de prática arqueológica usado para estudar seus registros que, até agora, não foi bem-sucedido em achar seus restos esqueletais. No futuro, a pesquisa local será especialmente importante para determinar os tipos e as funções de estruturas paisagísticas e/ou sítios habitacionais que foram utilizados pelos primeiros americanos para enterrar seus mortos. Uma vez encontrados esses locais poderemos reconstruir as primeiras adaptações biológicas e culturais bem como os padrões de sepultamento para então compreender melhor os feitos socioculturais dos primeiros americanos.

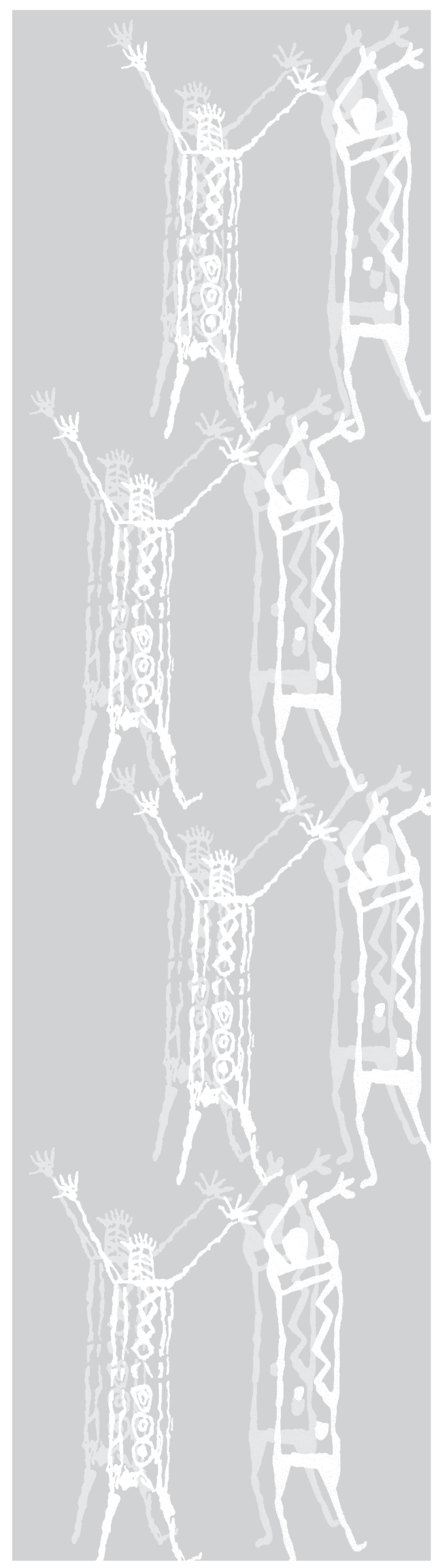




\section{BIBLIOGRAFIA}

ALLEN, J.; O’CONNELL, J. (eds.). “Transitions: Pleistocene to Holocene in Australia and Papua New Guinea”, in Antiquity, 69, Special Edition, 1995.

ALLISON, M. “Chile’s Ancient Mummies”, in Natural History, 94, 1985, pp. 74-8I.

BIANCHI, N. O.; BAILLIET, G.; BRAVI, C. M. "Peopling of the Americas as Inferred Through the Analysis of Mitochondrial DNA", in Brazilian Journal of Genetics, 18, 1995, pp. 66I-8.

BRYAN, A. "The Fluted Point Tradition in the Americas - One of Several Adaptations to Late Pleistocene American Environments", in R. Bonnichsen; K. Turnmire (eds.), Clovis: Origins and Adaptations, Center for the Study of the First Americans, Corvallis, Oregon, 1991, pp. 15-33.

CANN, R.; STONEKING, M.; WILSON, A. C. “Mitochondrial DNA and Human Evolution”, in Nature, 325, 1987, pp. 3I-6. CHAUCHAT, C. "Early Hunter-gatherers on the Peruvian Coast", in R. Keatinge (ed.), Peruvian Prehistory, Cambridge University Press, 1989, pp. 4I-66.

COLLINS, M. "Rockshelters and the Early Archeological Record in the Americas", in T. Dillehay; D. Meltzer (eds.), The First Americans: Search and Research, Florida, CRC Press, Boca Raton, 199I, Pp. 157-82.

DILLEHAY, T. D.; MELTZER, D. (eds.). The First Americans: Search and Research, Florida, CRC Press, Boca Raton, 1991.

DILLEHAY, T. D.; ARDILA, G.; POLITIS, G.; BELTRÃO, M. C. "Earliest Hunters and Gatherers of South America”, in Journal of World Prehistory, 6, 1992, pp. 145-204.

GONZALEZ, R. "Excavations in Bolivia”, in Anthropological Papers of the American Museum of Natural History, 35, 1985, pp. 329-507.

LAHR, M. M. The Evolution of Modern Human Diversity: a Study of Cranial Variation. Cambridge University Press, 1996.

LYNCH, T. "Glacial-Age Man in South America? A Critical Review”, in American Antiquity, 55, 1990, pp. 12-36.

MELTZER, D. “Why Don't We Know When the First People Came to North America”, in American Antiquity, 54, I989, pp. 47I-90.

MELTZER, D. “Monte Verde and the Pleistocene Peopling of the Americas”, in Science, 276, 1996, pp. 754-6.

NEVES, W. A.; PUCCIARELLI, H. M. "The Origin of the First South Americans: an Analisys Based on the Cranial Morphology of Early South American Human Remains”, in American Journal of Physical Anthropology, 8I, 1990, p. 274. NEVES, W. A.; PUCCIARELLI, H. M.; MEYER, D. "The Contribution of the Morphology of Early South- and NorthAmerican Skeletal Remains to the Understanding of the Peopling of the Americas", in American Journal of Physical Anthropology, Supplement, 16, 1993, Pp. 150-I.

QUILTER, J. Life and Death at Paloma: Society and Mortuary Practices in a Preceramic Peruvian Village. lowa City, University of lowa Press, 1989.

SALZANO, F. "DNA, Proteins and Human Diversity", in Brazilian Journal of Genetics, 18, 1995, pp. 645-50.

SCHIAPPACASSE, V.; NIEMEYER, H. Descripción y Análisis Interpretativo de un Sitio Arcaico Temprano en la Quebrada de Camarones. Santiago, Publicación Ocasional, 4I, Museo Nacional de Historia, 1985.

STANFORD, D. “Clovis Origins and Adaptations: an Introductory Perspective”, in R. Bonnichsen; K. Turnmire (eds.), Clovis: Origins and Adaptations, Oregon, Center for the Study of the First Americans, Corvallis, 1991, pp. 15-33.

STEELE, D. G.; POWELL, J. F. "Peopling of the Americas: Paleobiological Evidence”, in Human Biology, 64, 1992 , pp. 303-36. STOTHERT, K. “The Preceramic Las Vegas Culture of Coastal Ecuador”, in American Antiquity, 50, 1985, pp. 6I3-37.

TANKERSLEY, K. "A Close Look at the Big Picture: Early Paleoindian Lithic Procurement in the Midwestern United States”, in C. Ellis; J. Lothrop (eds.), Eastern Paleoindian Lithic Resource Use, 1989, pp. 259-92.

TAYLOR, R. E.; PAYEN, L. A.; PRIOR, C. A.; SLOTA JR., P. J.; GILLESPIE, R.; GOWLETT, J. A.; HEDGES, R. E.; HULL, A. J.; ZABEL, T. H.; DONAHUE, D. J.; BERGER, R. "Major Revisions in the Pleistocene Age Assignments for North American Human Skeletons by C-I 4 Accelerator Mass Spectrometry: None Older than II,000 C-14 Years Ago", in American Antiquity, 50, 1985, PP. I38-45.

TORRONI, A.; WALLACE, D. “mtDNA Haplogroups in Native Americans”, in American Journal of Human Genetics, 56, 1995, p. I.234.

TRINKHAUS, E.; SHIPMAN, P. The Neanderthals: Changing the Image of Mankind., New York, Alfred Knopf, 1992.

TURNER II, C. G. "Dental Evidence for the Peopling of the Americas", in R. Shutler (ed.), Early Man in the New World, Sage Publications, I983, pp. 34-55.

WOLPOFF, M. "Multiregional Evolution: the Fossil Alternative to Eden”, in P. Mellars; C. Stringer (eds.), The Human Revolution, Scotland, Edinburgh University Press, 1984, pp. 62-108.

ZAGO, M.; MELO SANTOS, E.; CLEGG, J.; GUERREIRO, J.; MARTINSON, J.; NORWICH, J.; FIGUEIREDO, M. “a-Globin Gene Haplotypes in South American Indians”, in Human Biology, 67, 1995, Pp. 535-42. 